\title{
Impacto da nutrição na recuperação do sistema imunológico em esportes de endurance
}

- O exercício, por si só, é um estímulo hábil em promover respostas e adaptações imunológicas benéficas, de forma aguda e crônica;

- A principal citocina expressada após o exercício é a IL-6, que possui efeitos sistêmicos de caráter endócrino e contrarregulatório;

- Varáveis como intensidade, volume, tempo de descanso e frequência influenciam diretamente na resposta imune relacionada ao exercício;

- Em níveis adequados, o cortisol possui efeito anti-inflamatório e imunoprotetor;

- Um dos principais pontos-chave que influenciam no sistema imune e que deve ser modulado é o cortisol, principalmente com aportes cíclicos de carboidrato;

- Otimizar a qualidade do sono com oferta adequada de nutrientes e fitonutrientes também é ponto essencial na manutenção ótima do sistema imune;

- A reparação imunomuscular deve, também, receber grande atenção do nutricionista para acelerar a recuperação tecidual e imune pós-exercício;

- O exercício de endurance tem a capacidade de gerar hiperpermeabilidade intestinal, a qual podemos tratar este com butirato, vitamina $\mathrm{D}$, meditação e água, por exemplo.

\section{Referências bibliográficas}

1. CHEN, Y.; WONG, S.; WONG, C.; LAM, C.; HUANG, Y.; MING-FAI, P. The effect of a pre-exercise carbohydrate meal on immune responses to an endurance performance run. British Journal of Nutrition; 100:1260-1268, 2008.

2. NIEMAN, D.; DAVIS, J.; HENSON, D. et al. Carbohydrate ingestion influences skeletal muscle cytokine mRNA and plasma cytokine levels after a 3-h run. Journal of Applied Physiology; 94: 1917-1925, 2003.

3. COSTA, R.J.S. et al. The Effects of a High Carbohydrate Diet on Cortisol and Salivary Immunoglobulin A (s-IgA) During a Period of Increase Exercise Workload Amongst Olympic and Ironman Triathletes. International Journal of Sports Medicine; 26: 880-885, 2005.

4. GLEESON, M.; BISHOP, N.; STENSEL, D. et al. The anti-inflammatory effects of exercise: mechanisms and implications for the prevention and treatment of disease. Nature Reviews Immunology;11(9):607-15, 2011.

5. CHAMBERS, E.; HAWRYLOWIC, C. The Impact of Vitamin D on Regulatory T Cells. Current Allergy and Asthma Reports; 11:29-36, 2011.

6. LANCASTER, G.; FEBBRAIO, M.Graeme I. The immunomodulating role of exercise in metabolic disease. Trends in Immunology; 35(6):262-9, 2014. 